\title{
TREATMENT OF FINGERTIP INJURIES BY SPECIALISTS IN HAND SURGERY IN BRAZIL
}

\section{TRATAMENTO DE LESÕES DA PONTA DOS DEDOS POR ESPECIALISTAS EM CIRURGIA DA MÃO NO BRASIL}

\author{
Márcio Koul Matsumoto ${ }^{1}$, Marcela Fernandes ${ }^{1}$, Vinicius Ynoe de Moraes $^{1}$, Jorge Raduan Neto ${ }^{1}$, aldo Okamura ${ }^{1}$, \\ JoÃo Carlos Belloti ${ }^{1}$
}

1. Department of Hand Surgery Residency, Hospital Alvorada, São Paulo, SP, Brazil.

\section{ABSTRACT}

Objective: To verify if there is consensus about the treatment of each type of injury or amputation of the fingertips, and if there is a statistical difference among the treatment options according to the surgeon's length of time in the hand surgery specialty. Methods: A cross-sectional survey was conducted during the 37th Brazilian Congress of Hand Surgery, when one hundred and twenty questionnaires were randomly distributed. Observing the inclusion and exclusion criteria, ninety completed questionnaires were included. The answers were submitted to descriptive and inferential analysis with a significance level of $p<0.05$. Results: This study showed agreement of $63.3 \%$ for the treatment with statistical difference for dorsal oblique injury less than $1 \mathrm{~cm}$ with bone exposure for the $V Y$ advancement flap alternative; $46.7 \%$ for volar tip oblique injury with bone exposure less than $1 \mathrm{~cm}$ for the Cross Finger alternative; $47.8 \%$ for oblique thumb volar injury greater than $1 \mathrm{~cm}$ with no bone exposure to the Moberg alternative; $54.4 \%$ for thumb pulp injury up to $2.5 \mathrm{~cm}$ with bone exposure to the Moberg alternative with proximal release, and $92.2 \%$ for antibiotic use, for the "cephalexin" alternative. Conclusion: There is no consensus regarding the treatment of most types of fingertip lesions, with agreement of $45.4 \%$. When we subdivided by time group of specialty in hand surgery, there was an increase in agreement to $54.5 \%$ of the questions per subgroup. Further comparative studies are needed to assess the consensus among surgeons regarding the treatment of fingertip injury. Level of Evidence III; Cross-sectional survey.

Keyword: Finger injuries. Amputation, traumatic. Treatment. Cross-sectional studies.

\section{RESUMO}

Objetivo: Verificar se há consenso sobre o tratamento de cada tipo de lesão ou amputação da ponta do dedo e se há diferença estatística entre as opções de tratamento de acordo com o tempo em que o cirurgião atua na especialidade de cirurgia da mão. Métodos: Pesquisa transversal realizada durante o $37^{\circ}$ Congresso Brasileiro de Cirurgia da Mão, quando foram distribuídos cento e vinte questionários de forma aleatória. Observando-se os critérios de inclusão e exclusão, noventa questionários respondidos foram incluídos. As respostas foram submetidas a análise descritiva e inferencial com índice de significância de $p<0,05$. Resultados: Este estudo apresentou concordância no tratamento com diferença estatística para lesão oblíqua dorsal menor que $1 \mathrm{~cm}$ com exposição óssea para a alternativa de retalho de avanço VY com 63,3\%; lesão oblíqua volar com exposição óssea menor que $1 \mathrm{~cm}$ para a alternativa Cross Finger com 46,7\%; lesão oblíqua volar do polegar maior de $1 \mathrm{~cm}$ sem exposição óssea para a alternativa Moberg com 47,8\%; lesão da polpa do polegar com até 2,5 cm com exposição óssea para a alternativa Moberg com liberação proximal com 54,4\% e uso de antibióticos para a alternativa "cefalexina" com 92,2\%. Conclusão: Não há consenso quanto ao tratamento da maioria dos tipos de lesão da ponta do dedo, sendo que houve concordância em 45,4\%. Quando subdividimos por grupo de tempo de especialização em cirurgia de mão, verificou-se aumento da concordância para 54,5\% das questões por subgrupo. Há necessidade de realização de novos estudos comparativos para avaliarmos o consenso entre os cirurgiões com relação ao tratamento da lesão das pontas dos dedos. Nível de evidência III; Pesquisa transversal.

Descritores: Lesões dos dedos. Amputação traumática. Tratamento. Estudos transversais.

Citation: Matsumoto MK, Fernandes M, Moraes VY, Neto JR, Okamura A, Belloti JC. Treatment of fingertip injuries by specialists in hand surgery in Brazil. Acta Ortop Bras. [online]. 2018;26(4):294-9. Available from URL: http://www.scielo.br/aob.

\section{INTRODUCTION}

A lack of safety in the workplace, coupled with human failures related to incompetence, recklessness, alcohol use, and unpreparedness for performing high-risk activities, leads to finger amputations, with significant economic and social implications. ${ }^{1}$ These types of injuries are more common in men between 20 and 45 years of age. In terms of prevalence, amputation of the index finger is the most

All authors declare no potential conflict of interest related to this article. 
common, with $28 \%$, followed by the middle finger with $24 \%$, the ring finger with $21 \%$, the little finger with $14 \%$, and the thumb with $13 \%{ }^{2}$ A fingertip amputation is the most common type of amputation and, at the same time, is the type that causes the most controversy. ${ }^{3}$ Extensive surgical experience is essential in treating these injuries because, otherwise, there is a risk of delayed return to work, persistent pain, and serious loss of finger function. ${ }^{4}$ Therefore, it is important to be familiar with the treatment options available for these injuries, in order to provide patients with good functional and esthetic results. Although reimplantation of the amputated fingertip may be the best way to achieve esthetic and functional reconstruction, it is not always possible.

Although it is generally agreed that the length of the thumb should be maintained, there is less agreement around the need and the means to maintain the length of the other fingers. Various ingenious techniques have been developed to bring the local skin forward or transfer the skin from an adjacent finger to ensure coverage of an area of exposed bone. A technique for microvascular reimplantation of an amputated fingertip has also been described. ${ }^{5}$ Other factors that are assessed can be divided into patient-related factors (hand dominance, occupation, age, expectations, previous injuries, smoking, comorbidities), surgeon-related factors (prior experience, training, microsurgical skills), and institutional factors (operating room, equipment, and staff availability). ${ }^{6}$

The general methods used to reconstruct a finger with an amputated distal portion include secondary intention healing, microreimplantation, revision amputation, local and regional flap, skin graft, and composite graft. ${ }^{6,7}$ Microreimplantation is beneficial if there is an injury in Tamai zone I that is distal to the lunule, or a crush injury or avulsion injury of the fingertip in Tamai zone II that is between the distal interphalangeal joint and the lunule, because its use is restricted in reimplantation. ${ }^{6}$

Additionally, the composite graft has a high success rate, with good results in the treatment of non-reimplantable fingers in pediatric patients, but a success rate as low as around $20 \%$ in adults has also been reported. ${ }^{7,8}$ In finger injuries too distally-located to be treated by microsurgery, there are options to avoid shortening of the finger. These include composite grafting and changing the dressing on the stump, which would be essential for secondary intention healing of the finger.

Therefore, there is no set of rules that serves as a satisfactory guide for applying each of these techniques. Each surgeon, in consultation with each patient, should choose the type of coverage that appears to best fit the needs of the individual and the technical skills of the surgeon. Regardless of the treatment selected, the objectives of preserving functional length and restoring adequate sensitivity remains the same.

Although there are several ways to treat an injury or amputation of the fingertip, there is no consensus around the choice of surgical technique to be used under given conditions.

This study will be based on the hypothesis that different surgeons treat the same conditions differently (heterogeneity), according to their time of experience in the specialty.

The objective of the study is to confirm the types of treatment used, and to determine whether there is consensus around each type of fingertip injury or amputation and whether there is a statistical difference in treatment option between surgeons with different lengths of time working in the specialty.

\section{MATERIALS AND METHODS}

The data collection was conducted at the 37th Brazilian Hand Surgery Conference in Belo Horizonte (MG) during the period March 30,2017 to April 1, 2017, with a sample number of 90 questionnaires.
For this study, a structured questionnaire (Attachment 1) was applied, consisting of 13 pertinent work-related questions. This study was approved by the Research Ethics Committee of the institution under approval protocol number 69454417.7.0000.5533.

The inclusion criteria were physicians specializing in hand surgery recognized by the SBCM [Brazilian Hand Surgery Society] and residents in hand surgery at an SBCM- and MEC [Ministry of Education and Culture]-accredited service. The exclusion criteria were professions other than those mentioned above, and foreign physicians.

\section{Interventions}

During the 37th CBCN, a hundred and twenty questionnaires were randomly distributed to the conference participants (medical residents or medical specialists in hand surgery), without identification and, therefore, with no need for the ICF. Of these, thirty were excluded because they were incomplete, or because the respondents either worked in other specialties or were foreigners, resulting in ninety questionnaires to be included and considered in the analysis of the final results.

\section{Primary outcome}

To obtain self-reported assessments about the preferred treatment for fingertip injury from hand surgery specialists, and to determine whether there is any statistical difference in the option chosen for each question evaluated.

Secondary outcomes

To confirm whether there is any statistical difference in treatment option between subgroups based on length of time working in the Hand Surgery specialty - residents, less than 5 years, and more than 5 years - as an indirect indicator of the number of cases treated, technical experience, and results observed.

Statistical Analysis

The data were presented in descriptive form as a central trend measurement (average) associated with a dispersion variable (standard deviation). For the percentages and averages, a confidence interval (Cl 95\%) and a level of significance of $5 \%(<0.05)$ were used, with a sampling error of $10 \%$ for the sampling proportion. The Statistical Package for Social Science for Windows (SPSS V20), minitab 16, Excel office 2010 was used for these calculations. ${ }^{6,7}$

\section{RESULTS}

For the primary outcome, the percentages and relationship between the answers to each question will be analyzed one by one, comparing them for any correlation or concordance in the treatment of fingertip injury, and for any statistical difference in the chosen treatment option (Table 1).

Most of the respondents were from the Southeast Region (58.9\%) and, among the three groups, the most prevalent was the group with over 5 years of experience (38.9\%).

In question 3 (Table 1, question 3) about emergency treatment for a fingertip injury of less than $1 \mathrm{~cm}$ without exposed bone, there was no concordance on treatment, with statistical difference, but the preferred option was secondary intention healing with $47.8 \%$, followed by $V Y$ advancement flap with $41.1 \%$, both with statistical difference when compared to the other alternatives. When we compared by time working in the specialty, there was concordance, with statistical difference, in the subgroup of residents for the VY advancement flap option, with $70.8 \%$, and also for the subgroup with more than 5 years of experience for the secondary intention healing option, with $60 \%$.

In question 4 (Table 1, question 4) about emergency treatment for a fingertip injury greater than $1 \mathrm{~cm}$ without exposed bone, there was no concordance around treatment, but the preferred option was 
secondary intention healing. Of those who selected other options (17 participants), 50\% chose homodigital flap and the other 50\% chose VY advancement flap. When we compared by time working in the specialty (Table 3, question 4), there was concordance, with statistical difference in the up to 5 years subgroup for the secondary intention healing option with $48.4 \%$.

In question 5 (Table 1, question 5) about emergency treatment for a dorsal oblique fingertip injury less than $1 \mathrm{~cm}$ with exposed bone, there was concordance, with statistical difference, for the VY advancement flap with $63.3 \%$. When we compared by time working in the specialty (Table 2, question 5) there was statistically significant concordance in the up to 5 years and more than 5 years subgroups for the VY advancement flap option, with $71 \%$ and $74 \%$, respectively.

In question 6 (Table 1, question 6) about emergency treatment for a volar oblique fingertip injury less than $1 \mathrm{~cm}$ with exposed bone, there was concordance, with statistical difference, for the cross finger flap option, with $46.7 \%$. When we compared by time working in the specialty (Table 2, question 6), there was a statistical difference in the up to 5 years subgroup for the cross finger flap option, with $67.7 \%$.

In question 7 (Table 1, question 7) about emergency treatment for a transverse fingertip injury less than $1 \mathrm{~cm}$ with exposed bone, there was no concordance around the treatment, but the preferred option was the VY advancement flap at $50 \%$ followed by Kutler at $37.8 \%$, both with statistically difference compared to the other alternatives. When we compared by time working in the specialty (Table 2, question 7), there was concordance, with statistical difference in the up to 5 years subgroup for the Kutler flap option with $61.3 \%$ and also for the more than 5 years subgroup for the VY advancement flap option with $74.3 \%$.

In question 8 (Table 1, question 8) about emergency treatment for a volar oblique injury of the distal phalanx of the thumb of less than $1 \mathrm{~cm}$ without exposed bone, there was no concordance around the treatment, but the preferred option was secondary intention healing at $55.6 \%$ followed by $V Y$ advancement flap at $33.3 \%$, both with statistical difference when compared to the other alternatives. When we compared by time working in the specialty (Table 1, question 8) there was concordance with statistical difference for the up to 5 years and more than 5 years subgroups for secondary intention healing with $58.1 \%$ and $65.7 \%$, respectively.

In question 9 (Table 1, question 9) about emergency treatment for a volar oblique injury of the distal phalanx of the thumb greater than $1 \mathrm{~cm}$ without exposed bone, there was concordance with statistical difference for the Moberg alternative with $47.8 \%$. When we compared by time working in the specialty (Table 3, question 9), there was a concordance with statistical difference for the residents and the more than 5 years subgroups for the Moberg flap option, with $54.2 \%$ and $54.3 \%$, respectively.

In question 10 (Table 1, question 10) about emergency treatment for a transverse injury of the distal phalanx of the thumb less than $1 \mathrm{~cm}$ with exposed bone, there was no concordance, but the preferred option was the VY advancement flap at $46.7 \%$ followed by Kutler at $28.9 \%$, both statistically different from the other alternatives. When we compared by time working in the specialty (Table 3, question 10), there was concordance with statistical difference in the up to 5 years subgroup for the VY advancement flap option, with $58.1 \%$. In question 11 (Table 1, question 11) about emergency treatment for a volar oblique injury of the distal phalanx of the thumb less than $1 \mathrm{~cm}$ with exposed bone, there was no concordance with statistical difference, but the cross finger flap was the treatment of reference. When we compared by time working in the specialty (Table 3, question 11), there was no concordance with statistical difference in any of the subgroups.
Table 1

\begin{tabular}{c|c}
\hline Question 1 & \\
\hline South & \\
\hline Southeast & \\
\hline North & \\
\hline Northeast & \\
\hline Central-West & \\
\hline Question 2 & \\
\hline resident & \\
\hline less than 5 years & \\
\hline more than 5 years & \\
\hline Question 3 & \\
\hline Occlusive dressing and & \\
\hline secondary cover dressing & \\
\hline Secondary intention healing & \\
\hline VY advancement flap & \\
\hline Full-thickness skin graft & \\
\hline Other & \\
\hline Question 4 &
\end{tabular}
\begin{tabular}{|c|c|c|}
$\mathrm{N}$ & $\%$ & P-value \\
\hline
\end{tabular}

Secondary intention healing Thenar flap

Cross finger flap

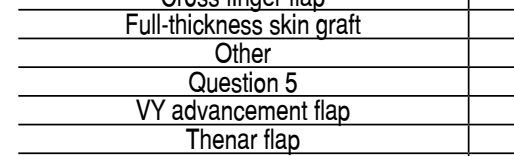

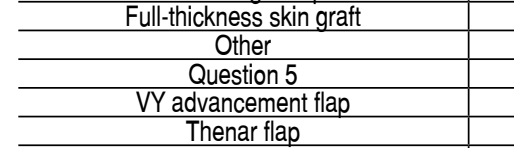
Bone shortening and primary closure Secondary intention healing

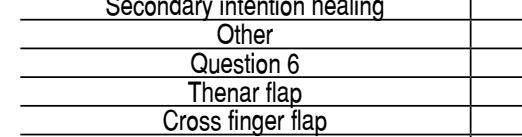

Subcutaneous coverage and secondary intention healing Bone shortening and primary closure

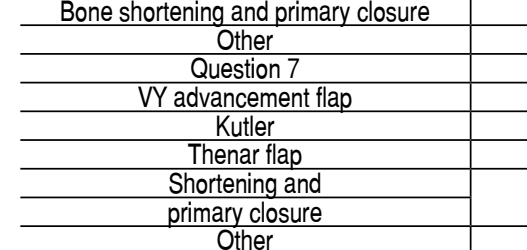

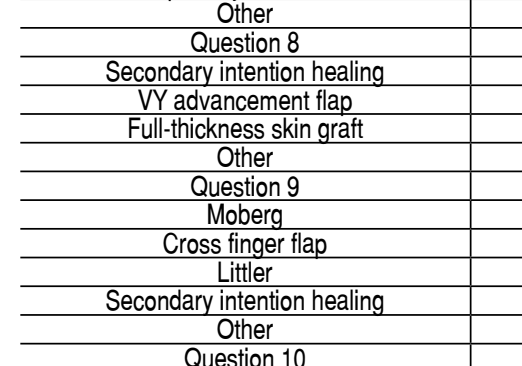
\begin{tabular}{c|}
\hline Question 10 \\
\hline VY advancement flap \\
\hline Kutler
\end{tabular}

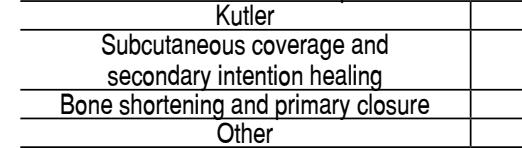

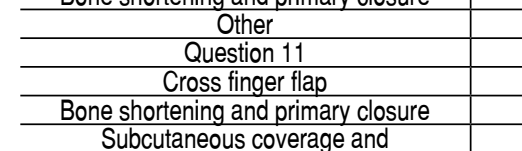

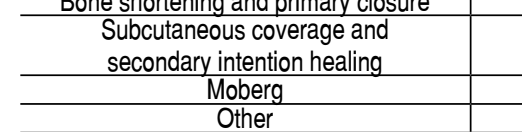

\begin{tabular}{c|c|c|c}
\hline Moberg & 9 & $9,98 \%$ & 0,03 \\
\hline Other & 11 & $11,10 \%$ & 0,035 \\
\hline Question 12 & $\mathrm{N}$ & $\%$ & P-value \\
\hline Moberg with proximal release & 49 & $54,40 \%$ & Ref. \\
\hline Cross finger flap & 7 & $7,80 \%$ & $<0,001$ \\
\hline Innervated cross finger & 9 & $10,00 \%$ & $<0,001$ \\
\hline Littler & 22 & $24,40 \%$ & $<0,001$ \\
\hline Other & 3 & $3,30 \%$ & $<0,001$ \\
\hline Question 13 & $\mathrm{N}$ & $\%$ & P-value \\
\hline Cephalexin & 83 & $92,20 \%$ & Ref. \\
\hline Oxacillin & 1 & $1,10 \%$ & $<0,001$ \\
\hline Ciprofloxacin & 1 & $1,10 \%$ & $<0,001$ \\
\hline Other & 5 & $5,60 \%$ & $<0,001$ \\
\hline No & 0 & 0 & $<0,001$ \\
\hline
\end{tabular}


In question 12 (Table 1, question 12) about emergency treatment for an injury of the flesh of the thumb up to $2.5 \mathrm{~cm}$ with exposed bone, there was concordance with statistical difference for the Moberg with proximal release alternative with $54.4 \%$. When we compared by time working in the specialty (Table 3, question 12), there was concordance with statistical difference in resident and up to 5 years subgroups for the Moberg with proximal release option, with $50 \%$ and $74.2 \%$, respectively.

In question 13 (Attachment 1, question 13) about emergency treatment with antibiotics, there was concordance with a statistical difference for the Cephalexin alternative, with $92.2 \%$. When we compared by time working in the specialty (Table 3, question 13), there was concordance with statistical difference in all three subgroups for the Cephalexin alternative, with $95.8 \%, 93.5 \%$, and $88.6 \%$, respectively

Table 2.

\begin{tabular}{|c|c|c|c|c|c|c|c|c|c|}
\hline \multirow{2}{*}{ destion 3} & \multicolumn{3}{|c|}{ resident } & \multicolumn{3}{|c|}{ less than 5 years } & \multicolumn{3}{|c|}{ more than 5 years } \\
\hline & 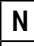 & $\%$ & P-value & $\mathbf{N}$ & $\%$ & P-value & $\mathbf{N}$ & $\%$ & P-value \\
\hline $\begin{array}{l}\text { and } \\
\text { cove }\end{array}$ & 1 & $4.2 \%$ & 001 & 4 & $12.9 \%$ & 001 & 4 & $\mid 11.4 \%$ & 0.0 \\
\hline $\begin{array}{r}\text { second } \\
\text { intention } r\end{array}$ & 6 & $25.0 \%$ & 001 & 16 & $51.6 \%$ & Ref. & 21 & $60.0 \%$ & Ref. \\
\hline Y advancement flap & 17 & $70.8 \%$ & Ref. & 10 & $32.3 \%$ & 23 & 10 & $28.6 \%$ & 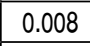 \\
\hline other & 0 & $0.0 \%$ & $<0.001$ & 1 & $3.2 \%$ & $<0.001$ & 0 & $0.0 \%$ & 0.001 \\
\hline \multirow{2}{*}{ Question 4} & \multicolumn{3}{|c|}{ resident } & \multicolumn{3}{|c|}{ less than 5 years } & \multicolumn{3}{|c|}{ more than 5 years } \\
\hline & $\mathbf{N}$ & $\%$ & -value & $\mathbf{N}$ & $\%$ & P-value & $\mathbf{N}$ & $\%$ & P-value \\
\hline $\begin{array}{r}\text { secon } \\
\text { intention }\end{array}$ & 4 & $16.7 \%$ & 0.104 & 15 & $48.4 \%$ & Ref. & 9 & $25.7 \%$ & Ref. \\
\hline thena & 8 & $33.3 \%$ & 763 & 2 & $6.5 \%$ & 0.001 & 4 & $11.4 \%$ & .124 \\
\hline cross fi & s & 3 & & & 1 & .007 & 5 & $\%$ & 232 \\
\hline $\begin{array}{r}\text { full-thick } \\
\text { skin gr }\end{array}$ & & $\%$ & 0.004 & 6 & $\%$ & 16 & 8 & $\%$ & 780 \\
\hline . & & $8.3 \%$ & 016 & 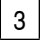 & $9.7 \%$ & $<0.001$ & 9 & $25.7 \%$ & Ref. \\
\hline \multirow{2}{*}{ Question 5} & \multicolumn{3}{|c|}{ resident } & \multicolumn{3}{|c|}{ less than 5 years } & \multicolumn{3}{|c|}{ more than 5 years } \\
\hline & $\mathbf{N}$ & $\%$ & P-value & $\mathbf{N}$ & $\%$ & P-value & $\mathbf{N}$ & $\%$ & \begin{tabular}{|l|} 
P-value \\
\end{tabular} \\
\hline advanc & 10 & $41.7 \%$ & ef. & 22 & $71.0 \%$ & Ref. & 25 & $71.4 \%$ & Ref. \\
\hline then & 4 & $16.7 \%$ & 57 & 1 & 3200 & $<0.001$ & & $7 \%$ & 0.001 \\
\hline $\begin{array}{l}\text { one st } \\
\text { prim }\end{array}$ & 9 & 3 & 0.768 & 7 & $\%$ & 1 & 5 & $\%$ & $<0.001$ \\
\hline se & 0 & $0.0 \%$ & $<0.001$ & 1 & $3.2 \%$ & $<0.001$ & 1 & $2.9 \%$ & $<0.001$ \\
\hline othor & & $4.2 \%$ & 0.002 & 0 & $0.0 \%$ & $<0.001$ & 2 & $5.7 \%$ & $<0.001$ \\
\hline \multirow{2}{*}{ Question } & \multicolumn{3}{|c|}{ resident } & \multicolumn{3}{|c|}{ less than 5 years } & \multicolumn{3}{|c|}{ more than 5 years } \\
\hline & $\mathrm{N}$ & $\%$ & P-value & $\mathbf{N}$ & $\%$ & P-value & $\mathrm{N}$ & $\%$ & P-value \\
\hline & 6 & $25.0 \%$ & 525 & 0 & & 0.001 & 5 & $14.3 \%$ & 0.029 \\
\hline cross & 8 & $33.3 \%$ & of. & 21 & 67. & Ref. & 13 & $37.1 \%$ & Ref. \\
\hline $\begin{array}{l}\text { subcu } \\
\text { cover } \\
\text { secc }\end{array}$ & 5 & $20.8 \%$ & 30 & 3 & $9.7 \%$ & $<0.001$ & 2 & $.7 \%$ & 0.001 \\
\hline $\begin{array}{l}\text { one shorten } \\
\text { primary clc }\end{array}$ & 3 & $2.5 \%$ & 86 & 4 & $.9 \%$ & .001 & 3 & $6 \%$ & 0.004 \\
\hline other & 2 & $8.3 \%$ & 033 & 0 & $9.7 \%$ & .001 & 12 & $34.3 \%$ & 0.803 \\
\hline \multirow{2}{*}{ Question 7} & \multicolumn{3}{|c|}{ resident } & \multicolumn{3}{|c|}{ less than 5 years } & \multicolumn{3}{|c|}{ more than 5 years } \\
\hline & $\mathbf{N}$ & $\%$ & P-value & $\mathrm{N}$ & & P-value & $\mathbf{N}$ & $\%$ & P-value \\
\hline flap & 9 & & & 10 & & & 26 & & \\
\hline & 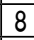 & & & 19 & & & 7 & & \\
\hline & & & & 0 & & .001 & 0 & $0.0 \%$ & $<0.001$ \\
\hline one shortening and & 4 & $16.7 \%$ & 0.104 & 1 & $3.2 \%$ & $<0.001$ & 0 & $0.0 \%$ & $<0.001$ \\
\hline 10 & 1 & 70 & $\overline{01}$ & 1 & $3.2 \%$ & 0.001 & 2 & $5.7 \%$ & 0.001 \\
\hline
\end{tabular}

Table 3.

\begin{tabular}{|c|c|c|c|c|c|c|c|c|c|}
\hline \multirow{2}{*}{ Question 8} & \multicolumn{3}{|c|}{ resident } & \multicolumn{3}{|c|}{ less than 5 years } & \multicolumn{3}{|c|}{ more than 5 years } \\
\hline & $\mathrm{N}$ & $\%$ & P-value & | & $\%$ & P-value & $\mathrm{N}$ & $\%$ & P-value \\
\hline $\begin{array}{r}\text { secon } \\
\text { intention }\end{array}$ & 9 & $37.5 \%$ & 558 & 18 & $58.1 \%$ & Ref. & 23 & $65.7 \%$ & Ref. \\
\hline Y advance & 11 & $45.8 \%$ & ef. & 10 & $\%$ & 041 & 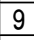 & $5.7 \%$ & 0.0 \\
\hline $\begin{array}{l}\text { full-thickne } \\
\text { skin graf }\end{array}$ & 3 & $12.5 \%$ & 0.011 & 3 & $9.7 \%$ & $<0.001$ & 3 & $8.6 \%$ & $<0.001$ \\
\hline her & 1 & $4.2 \%$ & $<0.001$ & 0 & $0.0 \%$ & $<0.001$ & 0 & $0.0 \%$ & $<0.001$ \\
\hline \multirow{2}{*}{ Question 9} & \multicolumn{3}{|c|}{ resident } & \multicolumn{3}{|c|}{ less than 5 years } & \multicolumn{3}{|c|}{ more than 5 years } \\
\hline & $\mathrm{N}$ & $\%$ & P-value & $\mathbf{N}$ & $\%$ & P-value & $\mathbf{N}$ & $\%$ & P-value \\
\hline IV & 13 & $54.2 \%$ & Ref. & 11 & $35.5 \%$ & Ref. & 19 & $54.3 \%$ & Ref. \\
\hline Cross & \begin{tabular}{|lll}
5 & \\
\end{tabular} & $20.8 \%$ & 017 & 7 & $22.6 \%$ & .263 & 3 & $8.6 \%$ & $=0.001$ \\
\hline & 3 & $12.5 \%$ & 002 & 2 & $.5 \%$ & 0.005 & 0 & $17.1 \%$ & 0.001 \\
\hline $\begin{array}{r}\text { second } \\
\text { intention } \mathrm{h}\end{array}$ & 2 & $8.3 \%$ & $<0.001$ & 10 & $32.3 \%$ & 0.788 & 6 & $7.1 \%$ & 0.001 \\
\hline he & & $4.2 \%$ & $<0.001$ & 1 & $3.2 \%$ & .001 & & $2.9 \%$ & $<0.001$ \\
\hline \multirow{2}{*}{ Question 10} & \multicolumn{3}{|c|}{ resident } & \multicolumn{3}{|c|}{ less than 5 years } & \multicolumn{3}{|c|}{ more than 5 years } \\
\hline & $\mathrm{N}$ & $\%$ & P-value & $\mathrm{N}$ & 10 & \begin{tabular}{|l|} 
P-value \\
\end{tabular} & $\mathrm{N}$ & $\%$ & lue \\
\hline advar & 9 & $37.5 \%$ & 768 & 18 & $58.1 \%$ & Bef. & 15 & $42.9 \%$ & Ref. \\
\hline & 10 & $41.7 \%$ & ef. & 16 & $19.4 \%$ & 002 & 10 & $28.6 \%$ & .212 \\
\hline $\begin{array}{r}\text { subcu } \\
\text { cover } \\
\text { secc } \\
\text { intentio }\end{array}$ & 1 & $\%$ & 02 & 5 & $16.1 \%$ & 01 & 3 & $\%$ & 01 \\
\hline $\begin{array}{l}\text { one short } \\
\text { primary }\end{array}$ & 4 & $16.7 \%$ & 57 & 2 & $6.5 \%$ & $<0.001$ & 2 & $.7 \%$ & 0.001 \\
\hline & 0 & $0.0 \%$ & $<0.001$ & 0 & $0.0 \%$ & 0.001 & & $14.3 \%$ & 0.008 \\
\hline \multirow{2}{*}{ Iestion 1} & \multicolumn{3}{|c|}{ resident } & \multicolumn{3}{|c|}{ less than 5 years } & \multicolumn{3}{|c|}{ more than 5 years } \\
\hline & N & $\%$ & P-value & $\mathrm{N}$ & $\%$ & \begin{tabular}{|l|} 
P-value \\
\end{tabular} & $\mathrm{N}$ & $\%$ & value \\
\hline Cros & 8 & $3.3 \%$ & Ref. & 14 & $45.2 \%$ & Ref. & 8 & $22.9 \%$ & 0.075 \\
\hline prin & 8 & $33.3 \%$ & Ref. & 10 & 5 & 0.297 & 5 & $\%$ & 0.000 \\
\hline sec & 7 & $29.2 \%$ & 755 & 4 & $12.9 \%$ & 0.005 & 7 & $20.0 \%$ & 0.039 \\
\hline & 1 & $4.2 \%$ & 0.010 & 0 & $9.7 \%$ & 0.002 & 15 & $42.9 \%$ & Ref. \\
\hline \multirow{2}{*}{ Jestion 1} & \multicolumn{3}{|c|}{ resident } & \multicolumn{3}{|c|}{ less than 5 years } & \multicolumn{3}{|c|}{ more than 5 years } \\
\hline & $\mathrm{N}$ & $\%$ & P-value & $\mathbf{N}$ & $\%$ & \begin{tabular}{|l|} 
P-value \\
\end{tabular} & $\mathrm{N}$ & $\%$ & P-value \\
\hline Mob & 2 & $50.0 \%$ & el. & 23 & $74.2 \%$ & Ret. & 14 & $40.0 \%$ & 0.808 \\
\hline 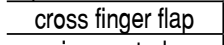 & 1 & $\%$ & 14 & 1 & $2 \%$ & .001 & 2 & $7 \%$ & 0.001 \\
\hline innervated & 3 & $12.5 \%$ & 0.005 & 3 & $9.7 \%$ & $<0.001$ & 3 & $8.6 \%$ & 0.00 \\
\hline er & & $16.7 \%$ & & 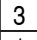 & $9.7 \%$ & .001 & 15 & $42.9 \%$ & Ref. \\
\hline Ollier & 1 & $4.2 \%$ & $<0.001$ & 1 & $3.2 \%$ & 0.001 & 1 & $2.9 \%$ & $<0.001$ \\
\hline \multirow{2}{*}{ Question 13} & \multicolumn{3}{|c|}{ resident } & \multicolumn{3}{|c|}{ less than 5 years } & \multicolumn{3}{|c|}{ more than 5 years } \\
\hline & $\mathrm{N}$ & 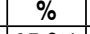 & P-value & $\mathrm{N}$ & $\%$ & P-value & $\mathrm{N}$ & 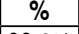 & P-value \\
\hline & 23 & $95.8 \%$ & & 29 & $93.5 \%$ & Ref. & 31 & $88.6 \%$ & . \\
\hline & 1 & $4.2 \%$ & .001 & 0 & $0.0 \%$ & $<0.001$ & 0 & $0.0 \%$ & 0.001 \\
\hline שוpre & 0 & $0.0 \%$ & & 1 & $3.2 \%$ & $<0.001$ & 0 & $0.0 \%$ & $<0.001$ \\
\hline 0 & 0 & $0.0 \%$ & $<0.001$ & 1 & $3.2 \%$ & $<0.001$ & 4 & $11.4 \%$ & $<0.00$ \\
\hline
\end{tabular}

\section{DISCUSSION}

This unprecedented work addresses one of the most important and prevalent themes in orthopedics and traumatology practice. Our objective was to map how the treatment of fingertip injuries are carried out in Brazil, in order to provide support for new studies and skills updating, as well as providing information to for student research projects of relevance to our field.

Our sample was representative in terms of consensus and non-consensus around the treatment of fingertip injuries, but new comparative studies of the literature need to be carried out.

We observed concordance, with statistical difference, among hand surgeons in relation to treatment of fingertip injuries in $45.4 \%$ of the cases. This concordance with statistical difference increased to $54.5 \%$ when evaluated by the time working in the specialty subgroups. 
The injuries for which we confirmed a statistically different consensus around treatment were: the VY advancement flap alternative for the dorsal oblique injury less than $1 \mathrm{~cm}$ with exposed bone at $63.3 \%$, the cross finger flap alternative for volar oblique fingertip injury less than $1 \mathrm{~cm}$ with exposed bone at $46.7 \%$, the Moberg alternative for volar oblique injury of the distal phalanx of the thumb greater than $1 \mathrm{~cm}$ without exposed bone at $47.8 \%$, the Moberg with proximal release alternative for injury of the flesh of the thumb up to $2.5 \mathrm{~cm}$ with exposed bone at $54.4 \%$, and the use of Cephalexin as the antibiotic of choice, with $92.2 \%$.

The surgical option and preference of the surgeon vary worldwide. The comparative study by Jin Bo Tang, MD et al. ${ }^{9}$ of the different continents reported the Moberg flap for the thumb and the VY advancement flap for the thumb and fingers as the first line treatments, which corroborates the result for injuries with exposed bone. In this same study, the author observed that there the use of the cross finger flap is decreasing, which diverges from our results in that there was concordance of $46.7 \%$ for volar oblique fingertip injury. In our evaluation of the subgroups, we observed a trend in the more than 5 years subgroup towards conservative treatment with secondary intention healing and weekly changes of occlusive dressing. This technique has gained more universal acceptance in recent years, as it provides excellent restoration of the contour, volume, and sensitivity for small to mid-size defects resulting from fingertip injury. ${ }^{10}$

\section{CONCLUSION}

There was no consensus around treatment for most types of fingertip injuries, although there was a concordance with statistical difference in $45.4 \%$. When we divided the surgeons by time working in the Hand Surgery field, there was an increase in concordance with statistical difference to $54.5 \%$ for the questions by subgroup, and among those with more than 5 years of experience, there was a trend towards conservative treatment with secondary intention healing and occlusive dressing.

\section{IMPLICATIONS FOR FUTURE RESEARCH}

Additional comparative studies need to be conducted, so that we can evaluate the consensus among surgeons on the treatment of fingertip injuries, analyzing the cost-benefit for each injury configuration according to the surgeon's experience, technical difficulty, the need to maintain functional and esthetic length, and complications, since there are no studies of this kind described in the literature.

AUTHORS' CONTRIBUTIONS: Each author made significant individual contributions to this manuscript. MKM $(0000-0001-6027-2890)^{\star}$, JCB $(0000-0003-$ $3396-479 X)^{*}$, and MF $(0000-0003-1646-6764)^{*}$ were the main contributors to the writing of the manuscript and the discussion of the results. VYM (0000$0002-4933-4007)^{\star}$ and $\mathrm{AO}(0000-0003-0115-2236)^{*}$ evaluated the statistical analysis data. MF and JRN developed and implemented the study protocol. JCB (0000-0002-0476-8768)* performed the final review of the manuscript. * ORCID (Open Researcher and Contributor ID).

\section{REFERENCES}

1. Pardini- traumatic injury hand $4^{\text {th }}$ Edition, pag 621

2. Pardini AG, Tavares KE, Fonseca Neto JA. Lesões da mão em acidentes do trabalho: análise de 1.000 casos. Rev Bras Ortop. 1990;25(5):119-24.

3. Louis DS. Amputation. In: Green DP, Hotckiss RM, Pederson WC (eds.). Operative hand surgery. 4 ed. Londres: Churchill Livisntone CO;1999. p. 48-94.

4. Tubiana R. The hand. Vol 111. Philadelphia: W.B. Saunders Co; 1998

5. Yamano Y. Replantation of the amputated distal part of the fingers. J Hand Surg Am. 1985;10(2):211-8.

6. Hirase Y. Postoperative cooling enhances composite graft survival in nasal-alar and fingertip reconstruction. Br J Plast Surg. 1993;46(8):707-11
7. Panattoni JB, De Ona IR, Ahmed MM. Reconstruction of fingertip injuries: surgical tips and avoiding complications. J Hand Surg Am. 2015;40(5):1016-24.

8. Moiemen NS, Elliot D. Composite graft replacement of digital tips. 2. A study in children. J Hand Surg Br. 1997;22(3):346-52.

9. Tang JB, Elliot D, Adani R, Saint-Cyr M, Stang F. Repair and Reconstruction of thumb and finger tip injuries: a global view. Clin Plast Surg 2014;41(3):325-59.

10. Germann G, Rudolf KD, Levin SL, Hrabowski M. Fingertip and Thumb Tip Wounds: Changing Algorithms for Sensation, Aesthetics, and Function. J Hand Surg Am. 2017;42(4):274-84 


\begin{tabular}{|c|c|}
\hline \multicolumn{2}{|l|}{ ttachment 1. Questionnaire } \\
\hline \multicolumn{2}{|c|}{ Treatment of fingertip injury by hand surgery specialists in Brazil } \\
\hline $\begin{array}{l}\text { 1. Which region do you work in? } \\
\text { a) South } \\
\text { b) Southeast } \\
\text { c) North } \\
\text { d) Northeast } \\
\text { e) Central-West }\end{array}$ & \multirow[t]{2}{*}{$\begin{array}{l}\text { 8. What treatment do you use for a volar oblique thumb injury of } \\
\text { less than } 1 \mathrm{~cm} \text { without exposed bone? } \\
\text { a) secondary intention healing } \\
\text { b) VY advancement flap } \\
\text { c) full-thickness skin graft } \\
\text { d) other: }\end{array}$} \\
\hline \multirow[b]{2}{*}{$\begin{array}{l}\text { 2. How long have you been specializing in hand surgery? } \\
\text { a) I am a resident } \\
\text { b) less than } 5 \text { years } \\
\text { c) from } 5 \text { - } 10 \text { years } \\
\text { d) from } 10 \text { - } 20 \text { years } \\
\text { e) more than } 20 \text { years }\end{array}$} & \\
\hline & \multirow{2}{*}{$\begin{array}{l}\text { 9. What treatment do you use for a volar oblique injury of the dista } \\
\text { phalanx of the thumb greater than } 1 \mathrm{~cm} \text { without exposed bone? } \\
\text { a) Moberg } \\
\text { b) cross finger flap } \\
\text { c) Littler } \\
\text { d) secondary intention healing } \\
\text { e) other }\end{array}$} \\
\hline \multirow{2}{*}{$\begin{array}{l}\text { 3. What emergency treatment do you use for a fingertip injury of } \\
\text { less than } 1 \mathrm{~cm} \text { without exposed bone? } \\
\text { a) occlusive dressing and secondary cover dressing } \\
\text { b) secondary intention healing } \\
\text { c) VY advancement flap } \\
\text { d) full-thickness skin graft } \\
\text { e) other: }\end{array}$} & \\
\hline & \multirow{2}{*}{$\begin{array}{l}\text { 10. What treatment do you use for a transverse injury of the distal } \\
\text { phalanx of the thumb of less than } 1 \mathrm{~cm} \text { with exposed bone? } \\
\text { a) VY advancement flap } \\
\text { b) Kutler } \\
\text { c) subcutaneous coverage and secondary intention healing } \\
\text { d) Moberg } \\
\text { e) other }\end{array}$} \\
\hline \multirow{2}{*}{$\begin{array}{l}\text { 4. What emergency treatment do you use for a fingertip injury } \\
\text { greater than } 1 \mathrm{~cm} \text { without exposed bone? } \\
\text { a) secondary intention healing } \\
\text { b) thenar flap } \\
\text { c) cross finger flap } \\
\text { d) full-thickness skin graft } \\
\text { e) other: }\end{array}$} & \\
\hline & \multirow{2}{*}{$\begin{array}{l}\text { 11. What treatment do you use for a volar oblique injury of the } \\
\text { distal phalanx of the thumb of less than } 1 \mathrm{~cm} \text { with exposed bone? } \\
\text { a) cross finger flap } \\
\text { b) shortening of the bone and primary closure } \\
\text { c) subcutaneous coverage and secondary intention healing } \\
\text { d) Moberg } \\
\text { e) other: }\end{array}$} \\
\hline \multirow{2}{*}{$\begin{array}{l}\text { 5. What emergency treatment do you use for a dorsal oblique } \\
\text { fingertip injury of less than } 1 \mathrm{~cm} \text { with exposed bone? } \\
\text { a) VY advancement flap } \\
\text { b) thenar flap } \\
\text { c) bone shortening and primary closure } \\
\text { d) secondary intention healing } \\
\text { e) other: }\end{array}$} & \\
\hline & \multirow{2}{*}{$\begin{array}{l}\text { 12. What treatment do you use for an injury to the thumb pad of } \\
\text { up to } 2.5 \mathrm{~cm} \text { with exposed bone? } \\
\text { a) Moberg with proximal release } \\
\text { b) cross finger flap } \\
\text { c) innervated cross finger flap } \\
\text { d) Littler } \\
\text { e) other: }\end{array}$} \\
\hline \multirow{2}{*}{$\begin{array}{l}\text { 6. What emergency treatment do you use for a volar oblique } \\
\text { fingertip injury of less than } 1 \mathrm{~cm} \text { with exposed bone? } \\
\text { a) thenar flap } \\
\text { b) cross finger flap } \\
\text { c) subcutaneous coverage and secondary intention healing } \\
\text { d) shortening and primary closure } \\
\text { e) other: }\end{array}$} & \\
\hline & \multirow{2}{*}{$\begin{array}{l}\text { 13. Do you prescribe antibiotics? } \\
\text { a) yes: } \\
\text { If yes, which one? } \\
1 \text { - Cephalexin } \\
2 \text { - Oxacillin } \\
3 \text { - Ciprofloxacin } \\
4 \text { - Other: } \\
\text { b) no }\end{array}$} \\
\hline $\begin{array}{l}\text { 7. What emergency treatment do you use for a transverse fingertip } \\
\text { injury of less than } 1 \mathrm{~cm} \text { with exposed bone? } \\
\text { a) VY advancement flap } \\
\text { b) Kutler } \\
\text { c) thenar flap } \\
\text { d) shortening and primary closure }\end{array}$ & \\
\hline
\end{tabular}

